\title{
Bilateral ureteral obstruction secondary to condylomata acuminata of the urinary bladder
}

\author{
PHILLIP C. GINSBERG, DO \\ JOSEPH J. WILLIAMS, MD \\ ROBERT L. KLAUS, MD
}

\section{Condyloma acuminatum is a viral infection of near epidemic proportions. Both men and women are affected equally. Most lesions are on the external genitalia and the mucous membranes of the urethra or the vagina. A rare occurrence of condyloma acuminata is involvement of the urinary bladder. To date, only 11 cases have been reported. We describe two additional cases, both with bilateral ureteral obstruction. Current urologic management and review of the literature are presented.}

Condylomata acuminata infections are considered to be viral in origin, and they are seen commonly in urologic or gynecologic practice. The lesions, which are thought to be caused by papovavirus,${ }^{1}$ usually affect the moist, mucocutaneous areas of the male and female perineum and genitalia. ${ }^{1-3}$ Rarely, the mucous membranes of the male urethra can become involved.

An exceedingly rare manifestation of condylomata acuminata is the involvement of the urinary bladder. Indeed, it seems that until now, only 11 cases have been reported ${ }^{1-9}$ in the English literature. Many of these cases have involved immunosuppressed patients.

In the two additional cases reported here, the patient had overwhelming bladder lesions with bilateral ureteral obstruction. Most importantly, the need for radical surgery for so-called benign disease is demonstrated. Also, the treatment and importance of differential diagnosis is emphasized.

\section{Report of cases}

Case 1

A 36 year-old woman was being followed by the internal medicine department for disseminated systemic sarcoidosis. She had demonstrated ocular, renal, cardiac, pulmonary, and cutaneous manifestations of this disease, and she was being treated with long-term, low-dose prednisone $(20 \mathrm{mg} / \mathrm{d})$. She had been seen by the urology de- partment for biopsy-proved vesical malacoplakia on several occasions.

During her last admission, she developed right-sided, dull flank pain and gross hematuria with clot retention. Physical examination revealed her to be well nourished and in moderate distress, with cutaneous lesions secondary to sarcoidosis. Examination of the perineum showed massive involvement of condylomata acuminata. Infusion urography revealed high-grade ureteral obstruction of the right renal unit and low-grade obstruction on the left (Fig 1). The ureters were visualized to the ureterovesical junction bilaterally.

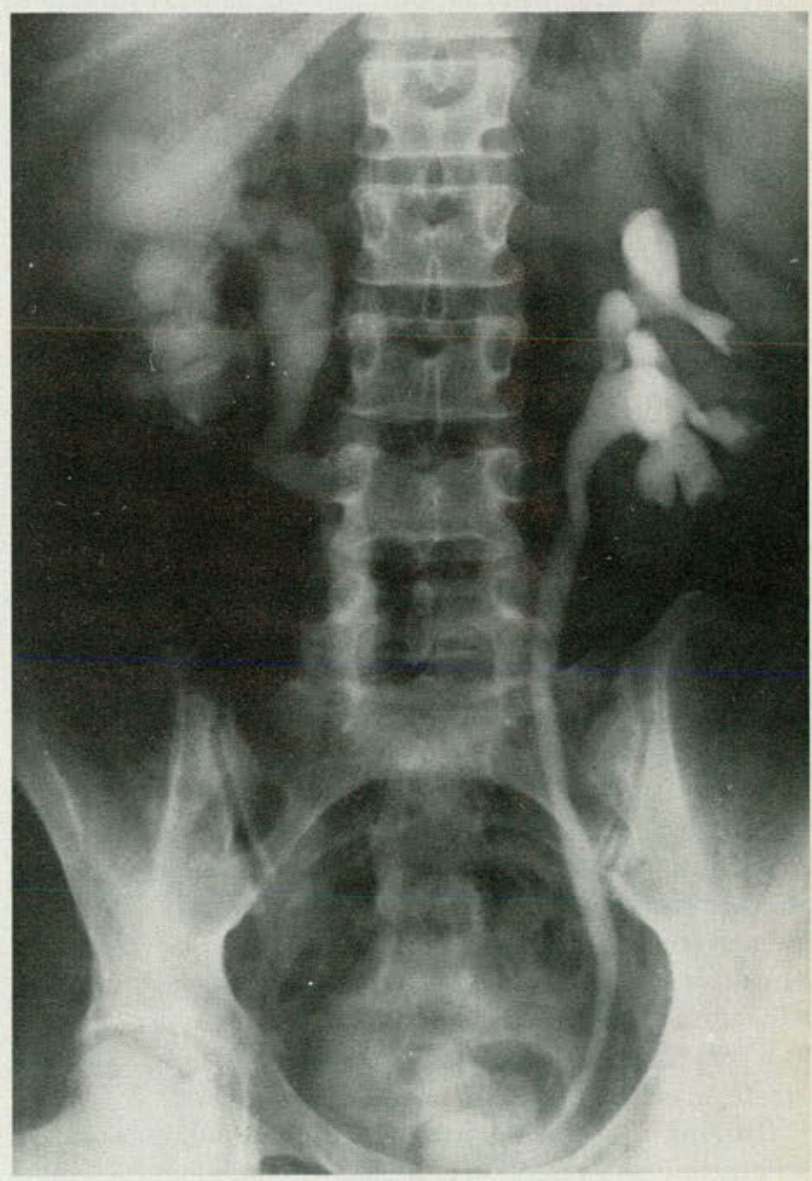

Fig 1. Infusion urogram revealing right-sided hydronephrosis secondary to ureterovesical obstruction; low-grade obstruction on the left (case 1). 
Cystoscopy showed the entire right side of the urinary bladder and trigone to be embedded with condylomata. The right ureteral orifice was obliterated, and the left side of the trigone was thickened and hyperemic. Neither ureteral orifice was identified; however, infusion of methylene blue demonstrated a patent, left ureter.

Transurethral resection and fulguration of the bladder lesions and extensive fulguration of the perineum were accomplished, with satisfactory postoperative results.

Pathologic specimens obtained during resection showed papillary structures covered by squamous epithelium, which were identified as condyloma acuminata. In no specimen was invasion of the submucosa identified, and no specimen was considered to be malignant.

The patient was disease free for two months postoperatively, but then she again presented with gross hematuria. Repeat cystoscopy confirmed the recurrence of condylomata acuminata, and transurethral resection was carried out. However, the patient had a second recurrence, and in addition to the right-sided ureteral obstruction there was progression to left-sided hydronephrosis. She refused cystectomy and diversion, and a decision was made to perform bilateral ureteral reimplantation into the unaffected dome of the bladder. Her ureteral obstruction was relieved, but several more recurrences have been treated by transurethral surgery. At this time, optimum therapy would by cystectomy, but to date she has refused it.

\section{Case 2}

A 42-year-old heterosexual man previously had been a professional football player and was in his usual state of good health until approximately three years prior to admission, when he discovered condylomata acuminata on his external genitalia and urethral meatus. Further study revealed involvement of the entire urethra and bladder. He presented with gross hematuria and intravesical clots.

At that time, he underwent transurethral resection of the bladder condyloma. He was evaluated thoroughly by an immunologist and found to have a competent immune system. During the past three years, he had had a total of nine transurethral bladder resections at several institutions.

A vaccine was made at one time and was tried with some transient success; however, the patient developed a pruritic rash and constitutional symptomatology and discontinued the vaccine therapy on his own. Only one month before admission, he underwent a 100-g transurethral resection of the bladder, with no further therapy. On admission, the patient had a hemoglobin value of $8.8 \mathrm{~g} / \mathrm{dL}$, and intravenous urography revealed bilateral ureteral obstruction (Fig 2).

During a subsequent admission, he underwent cystoscopy and resection of a bladder condylomata weighing $175 \mathrm{~g}$. Pathologic diagnosis was condyloma acuminata. Bilateral nephrostomy tubes were placed (Fig 3), and cystectomy was recommended for definitive ther-

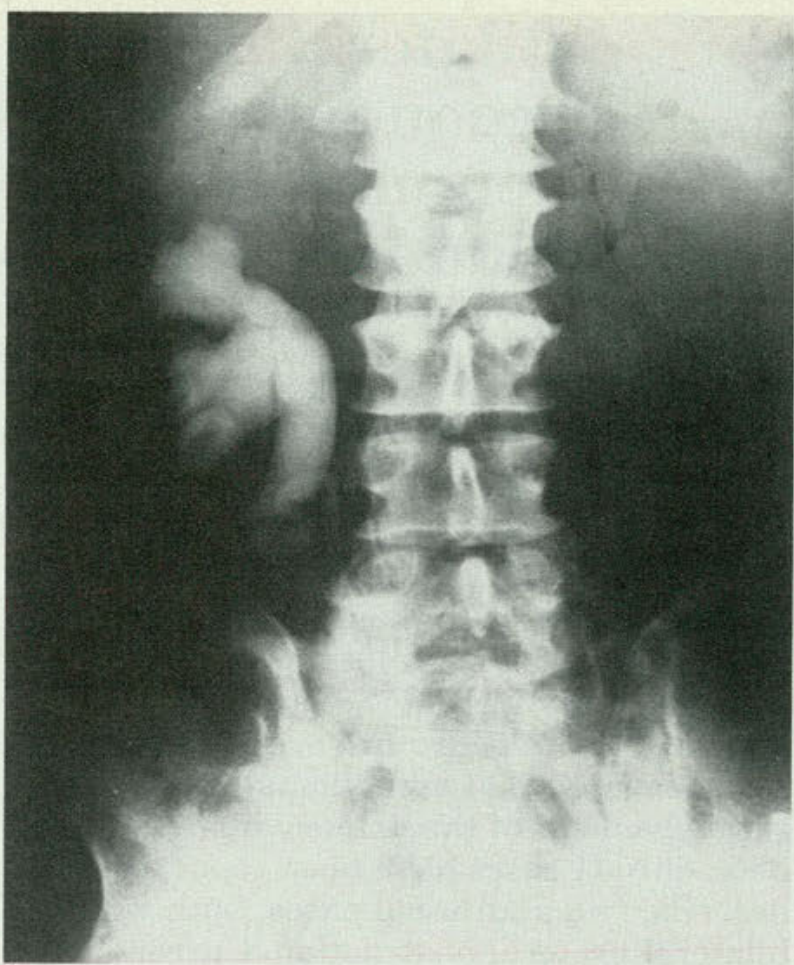

Fig 2. Nonvisualized left kidney on intravenous urogram (case 2).

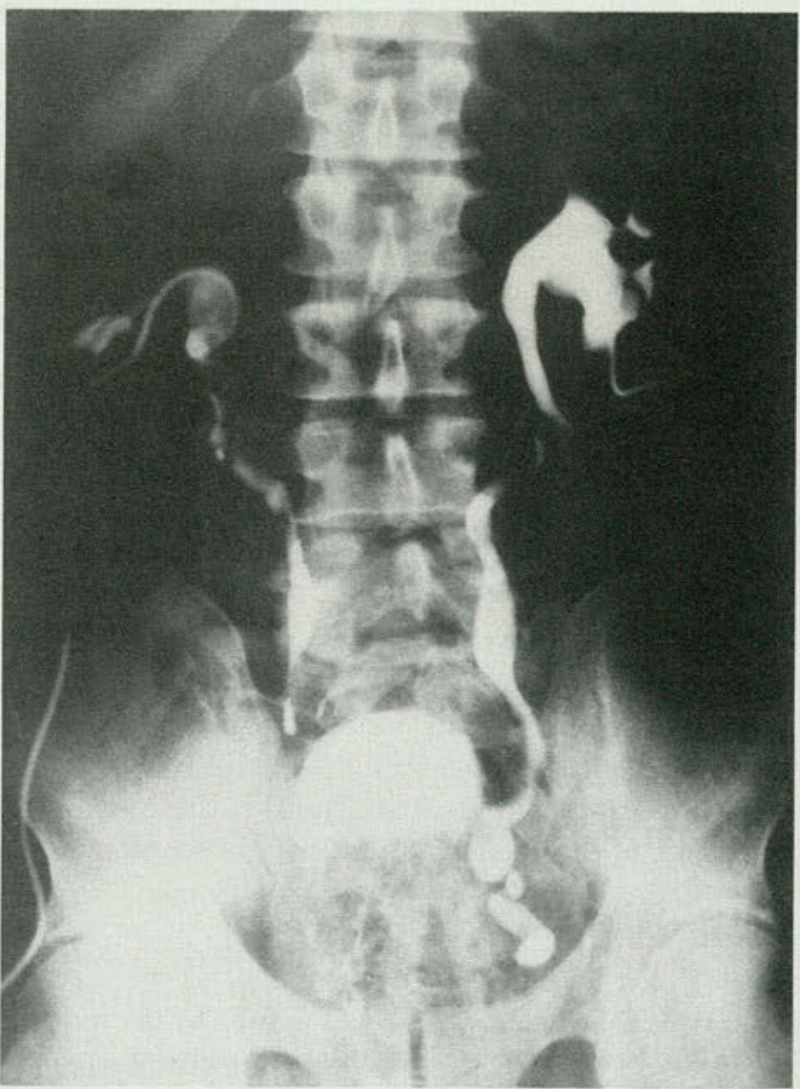

Fig 3. Left ureterovesical obstruction on bilateral nephrostogram (Case 2). 
apy. The patient refused this mode of therapy, opted for a trial diet therapy, and left the hospital weighing $165 \mathrm{lb}$.

He underwent further immunologic evaluation for acquired immunodeficiency syndrome, which proved to be negative. After intravenous hyperalimentation, he consented to further surgery, and total cystectomy and ileal conduct urinary diversion were carried out. He was discharged on the 21st postoperative day without nephrostomy tubes and with a 15 -lb weight gain.

\section{Discussion}

Condylomata acuminata is a wart-like lesion of a viral-induced proliferation of squamous epithelia. ${ }^{8}$ Under electron microscopy, sections of condylomata specimens show intranuclear virus particles. The virus has been identified as belonging to the papovavirus family. ${ }^{8}$ Transmission has been proved by inoculation of sterile filtrates of verrucous material. Usually the disease is spread by sexual activity, although patients without sexual history have been found to have condylomata. ${ }^{10}$ Most cases involve the external genitalia and perineum, but involvement of the urethra was reported in approximately five percent of cases. ${ }^{1}$ Most patients with urethral condyloma presented with symptoms of urethral discharge and dysuria, frequency, urgency, or a change in the urinary stream. Several reports ${ }^{1-9}$ of bladder involvement have been published (Table 1).

Bissada and associates ${ }^{6}$ suggest that bladder involvement can be prevented by early recognition of intraurethral condyloma followed by prompt and adequate therapy. The combination of perineal, urethral, and bladder involvement is, indeed, a serious situation. The etiology of this infection is not clear. Some authors postulate that predisposing factors, such as irritation from purulent discharges, poor hygiene, chronic inflammation, venereal diseases, and male phimosis, can be implicated. ${ }^{2,6,8}$ There have been reported cases of condylomata acuminata in renal allograft recipients receiving long-term immunosuppressive medication. ${ }^{11}$ Our female patient was treated with long-term, lowdose prednisone for her systemic sarcoidosis.

Many investigators stress that condylomata acuminata must be considered malignant when the bladder is involved. Others think that the histologic examination is of the utmost importance, because this lesion may be considered premalignant; it must be differentiated from squamous cell carcinoma and giant condyloma, the so-called BuschkeLowenstein tumors. Special emphasis should be placed on the cytologic criteria, including nuclear pleomorphism, mitosis, and abnormal maturation patterns for differentiation. ${ }^{2,12}$

Treatment of bladder involvement, despite its

\begin{tabular}{|c|c|c|c|c|}
\hline Author & Date & Cases & Involvement & Treatment \\
\hline $\begin{array}{l}\text { Kleiman and } \\
\text { Lancaster }^{4}\end{array}$ & 1962 & 1 & Bladder/urethra & Cystectomy \\
\hline $\begin{array}{l}\text { Lewis } \\
\text { et } \text { al }^{3}\end{array}$ & 1962 & 2 & Bladder/urethra & Cystectomy \\
\hline Hotchkiss 5 & 1968 & 1 & Bladder/urethra & Cystectomy \\
\hline $\begin{array}{l}\text { Bissada } \\
\text { et al } 6\end{array}$ & 1974 & 1 & Bladder/urethra & Cystectomy \\
\hline Nielson 7 & 1975 & 1 & Bladder/urethra & $\begin{array}{l}\text { TURB*/ } \\
\text { podophyllin }\end{array}$ \\
\hline $\begin{array}{l}\text { Masse } \\
\text { et al } 2\end{array}$ & 1976 & 1 & Bladder & TURB \\
\hline $\begin{array}{l}\text { Pettersson } \\
\text { et al } 8\end{array}$ & 1976 & 2 & Bladder & $\begin{array}{l}\text { TURB/ } \\
\text { podophyllin }\end{array}$ \\
\hline $\begin{array}{l}\text { DeBenedictis } \\
\text { et at } 1\end{array}$ & 1977 & 1 & Bladder/urethra & $\begin{array}{l}\text { TURB, } 5 \% \\
\text { 5-fluorouracil } \\
\text { cream }\end{array}$ \\
\hline $\begin{array}{l}\text { Keating } \\
\text { et at } 9\end{array}$ & 1985 & 11 & Bladder & Cystectomy \\
\hline $\begin{array}{l}\text { Ginsberg } \\
\text { et al }\end{array}$ & 1989 & 21 & Bladder/urethra & $\begin{array}{l}\text { TURB (1) } \\
\text { Cystectomy (1) }\end{array}$ \\
\hline
\end{tabular}

"benign" nature, has necessitated radical surgery (total cystectomy with urinary diversion). This is due, in part, to the theories of some surgeons regarding the malignant potential of this lesion, and, in part, to the symptoms resulting from bleeding, infection, and ureteral obstruction.

Mild cases of only perineal or distal urethral involvement have been treated by simple excision and fulgeration. ${ }^{7,13}$ Podophyllin has been widely used as a topic agent on the mucous membranes, with good results. ${ }^{14}$ There have been reports of excellent results using an autogenous vaccine in the treatment of condyloma acuminata of the external genitalia. ${ }^{15}$ There have been some mixed results using Thiotepa instillations for the treatment of intravesical lesions. ${ }^{16}$

Other therapies, including colchicine instillation and BCG injections have been shown to be effective in eradicating condylomata. ${ }^{17,18}$ Dretler and Klein ${ }^{19}$ have used 5\% 5-fluorouracil (5-FU) intraurethral cream with good success for intraurethral condyloma acuminata.

The recent inclusion of the neodymium:YAG laser into the urologic armamentarium shows promise in the treatment of this rare disease. The YAG laser has been used to treat intravesical tumors and stricture disease in the urethra. It also is an excellent tool for fulguration and hemorrhage control. Dr. L. H. Finkelstein and I plan to use our 
recently acquired YAG laser for treatment of both external and internal condylomata.

\section{Summary}

Our two cases bring to 13 the number of reports of condylomata acuminata of the bladder in the English literature. Our patients presented with gross hematuria, infection, and clot retention. Their infusion urograms revealed bilateral ureteral obstruction, and cystoscopy and biopsy confirmed condylomata acuminata involving the bladder.

The importance of differentiation from squamous cell carcinoma and demonstration of invasion, if present, must be stressed. Transurethral resection of the bladder has been shown to be effective for localized cases; there should be close follow-up with periodic cystoscopy and biopsy of questionable areas. Radical surgery should be reserved as a last resort.

In our cases, original therapy was aimed at hemostasis, and local method (transurethral resection of the bladder) was used. However, the overwhelming bladder involvement called for radical surgery, despite the fact that condylomata acuminata is a "benign" lesion and no squamous cell malignant degeneration was noted in the pathologic specimens. One patient refused cystectomy, but it is likely that such surgery will become mandatory in the future.

1. DeBenedictis TJ, Marmer JL, Praiss D: Intraurethral condylomas acuminata: Management and review of the literature. J Urol 1977;118:767769.

2. Masse S, Tosi-kruse A, Carmel M, et al: Condyloma acuminatum of bladder. Urology 1981;17:381-382.
3. Lewis HY, Wolf PL, Pierce JM: Condyloma acuminata of the bladder. J Urol 1962;88:248-252.

4. Kleiman H, Lancaster Y: Condyloma acuminata of the bladder. J Urol 1962;88:52-55.

5. Hotchkiss RS, Rouse AV: Papilomatosis of the bladder and ureters, preceded by condyloma acuminatum of the vulva. A case report. $J$ Urol $1968 ; 100: 723-725$.

6. Bissada NK, Cole AT, Fried FA: Extensive condyloma acuminata of the entire male urethra and the bladder. $J$ Urol 1974;112:201-203.

7. Nielson HV: Condyloma acuminata of the bladder. Scand J Urol Nephrol 1975;9:169.

8. Pettersson S, Hansson G, Blohme I: Condyloma acuminatum of the bladder. J Urol 1976;115:535-536.

9. Keating MA, Young RH, Carr CP, et al: Condyloma acuminatum of the bladder and ureter: Case report and review of the literature. $J$ Urol $1985 ; 133: 465-467$.

10. Redman JF, Meacham KR: Condyloma acuminata of the urethral meatus in children. $J$ Pediat Surg 1973;8:939-941.

11. Spencer ES, Anderson HK: Clinically evident, nonterminal infections with herpes viruses and the wart virus in immunosuppressed renal allograft recipients. $\mathrm{Br}$ Med $J$ 1970;3:251-254.

12. Machacek GF, Weakley DR: Giant condylomata acuminata of Buschke and Lowenstein. Arch Dermatol 1960;82:41-47.

13. Morrow RP Jr, McDonald JR, Emmett JL: Condyloma acuminata of the urethra. $J$ Urol 1952;68:909-911.

14. Kaplan JH, McDonald JR, Thompson GJ: Multicentric origin of papillary tumors of urinary tract. $J$ Urol 1951;66:792-804.

15. Powell LC Jr: Condyloma acuminatum. Clin Obstet Gynecol 1972;15:948-965.

16. Halverstadt DB, Parry WL: Thiotepa in the management of intraurethral condylomata acuminata. $J$ Urol 1969;101:729-731.

17. Gigax JH, Robinson JR: The successful treatment of intraurethral condylomata acuminata with colchicine. J Urol 1971;105:809-811.

18. Rosenberg JW, Askari S: Management of intraurethral condylomata acuminatum. J Urol 1973;110:686-687.

19. Dretler SP, Klein LA: The eradication of intraurethral condyloma acuminata with 5\% 5-fluorouracil cream. J Urol 1975;113:195-198.

From the Department of Medicine, Division of Urologic Surgery, Albert Einstein Medical Center, Philadelphia.

Reprint requests to Dr Ginsberg, Suite 503, 5401 Old York Rd, Philadelphia, 19141. 